DOI 10.31558/2519-2949.2020.1.14

УДК 327.8(73)«2017-2020»

ORCID ID: https://orcid.org/0000-0001-7492-6103

Захарченко А. М., Одеський національний університет імені I. I. Мечникова

\title{
ВІДНОСИНИ МІЖ США ТА ЄС В КОНТЕКСТІ ПРОБЛЕМ БЕЗПЕКИ БЛИЗЬКОГО СХОДУ В ПЕРІОД ПРЕЗИДЕНТСТВА Д. ТРАМПА
}

У статті аналізуються трансатлантичні відносини в близькосхідному контексті після приходу до Білого дому адміністрачї Д. Трампа. Зокрема, проведено порівняльний аналіз політики союзників щодо найважливіших регіональних проблем - іранської ядерної програми, арабськоізраїльського конфлікту та сирійської кризи; виявлено відмінності в підходах США та ЄС щодо зазначених проблем та визначено їхній вплив на стан відносин між двома акторами.

3'ясовано, щуо за часів перебування Д. Трампа на посаді президента, протиріччя у підходах трансатлантичних партерів до близькосхідної проблематики значно поглибилися. Це зумовлено його різким відходом від політики попередників, а також притаманним для нього одностороннім характером прийняття рішень, без консультачій із союзниками. Низка суперечливих кроків американського президента, таких як вихід з угоди щьоо іранської ядерної програми, беззастережна підтримка Ізраїлю, разом із перенесенням посольства США до Срусалиму $i$ визнанням ізраїльського суверенітету над Голанськими висотами, а також рімення про виведення американського контингенту з Сирії, не була підтримана Свропейським Союзом.

В той час як Сполучені Штати демонструють зниження інтересу до Близького Сходу, важливість регіону для Свропи зростає. Односторонні кроки адміністрачії Д. Трампа, а також розбіжності з СС у поглядах на важливі проблеми регіональної безпеки, спонукатимуть Європейський Союз до більш самостійної політики. Втім, низка об'єктивних обставин, насамперед, протиріччя всередині самого СС, не дозволяють йому виступати актором, здатним ефективно впливати на динаміку близькосхідних процесів. Якщо участь Вашингтона в регіоні продовжить слабшати, Свропа все частіше буде змушена співпрацювати з альтернативними впливовими акторами, такими як Росія та Китай, для просування свойх інтересів.

Ключові слова: США, СС, Близький Схід, проблеми безпеки, Д. Трамп.

Постановка проблеми. США та ЄС традиційно є впливовими зовнішніми акторами на Близькому Сході. Стабілізація цього стратегічно важливого регіону залишається одним 3 найважливіших напрямків як американської, так і європейської дипломатій. Обидва актори зацікавлені у врегулюванні регіональних конфліктів, просуванні демократії, а також ліквідації загроз поширення зброї масового ураження та ісламістського екстремізму.

Втім, незважаючи на спільність інтересів, у США та їхніх союзників в Свропі завжди були певні протиріччя у підходах до регіональних загроз. Показовим прикладом стала війна в Іраку 2003 р., під час якої тільки Великобританія приєдналася до Вашингтону у військовій операції проти режиму С. Хусейна. Іншим прикладом $є$ палестинсько-ізраїльський конфлікт, в якому Європейській Союз більш послідовно підтримує інтереси палестинців. Однак саме після приходу до влади в США Д. Трампа суперечності між Вашингтоном та його європейськими партнерами вийшли на новий рівень як за їхнім обсягом, так i за глибиною. Особливо яскраво це виглядає на контрасті із попередньою адміністрацією Б. Обами, за часів якої ці розбіжності були мінімальними.

Трансатлантичне співробітництво, його динаміка та проблемні моменти, $\epsilon$ важливими факторами, які необхідно враховувати як при аналізі близькосхідної політики цих двох міжнародних акторів, так і при аналізі регіональних процесів. Виходячи 3 цього, метою даної статті $є$ аналіз відносин між США та СС в контексті проблем безпеки Близького Сходу за часів адміністрації Д. Трампа. Ця мета реалізується шляхом реалізації наступних завдань:

1) провести порівняльний аналіз політики трансатлантичних союзників щодо трьох найважливіших регіональних проблем - іранської ядерної програми, арабсько-ізраїльського конфлікту та сирійської кризи; 
2) виявити відмінності в підходах США та ЄС щодо зазначених проблем та визначити їхній вплив на стан відносин між двома акторами;

3) дати прогноз щодо можливої еволюції трансатлантичних відносин у близькосхідному контексті.

Аналіз останніх досліджень та публікацій. Аналіз стану трансатлантичних відносин на Близькому Сході за часів адміністрації Д. Трампа ще не набув високого ступеня наукової розробки. Серед подібних робіт слід відзначити дві аналітичні доповіді європейських дослідників: К. Кауш з Фонду Маршала [7] та експерта Центру європейських реформ Л. Сказзері [17] .

Значно більша кількість робіт західних авторів присвячена дослідженою окремо політики США та ЄС в регіоні. Так, грунтовний критичний аналіз близькосхідної стратегії Д. Трампа демонструють в своїх роботах відомі американські фахівці - провідний співробітник Ради з міжнародних відносин М. Індик [6] та директор Близькосхідної програми Атлантичної ради В. Векслер [22]. Експерт «Карнегі - Свропа» М. Пєріні [10] та директор Паризького офісу Європейської ради з міжнародних відносин М. Рапнуіл [14], у свою чергу, аналізують особливості європейської регіональної політики. Підходи ЄС щодо іранської ядерної програми, а також перспективи взаємодії на цьому напрямку із Вашингтоном висвітлюють в своїх роботах експерти римського Інституту міжнародних справ Р. Алькаро та А. Дессі [1], французький дослідник К. Терме [21], а також фахівці Вашингтонського інституту близькосхідної політики Ч. Тепо та Е. ДеЛозер [20]. Б. Оппенхейм з Центру європейських реформ [8] та експерт Центру США та Європи Інституту Брукінгса К. Штельзенмюллер [19] аналізують підходи трансатлантичних союзників до близькосхідного мирного врегулювання.

Окремі аспекти вищезазначеної проблематики знайшли своє відображення в роботах українських фахівців: Дубовика В.А., Нагайчука В.І., Шведа В.О, Вонсовича О.С., Мудрієвської І.І., Дужої I.А. Втім, аналіз відносин між США та $\mathrm{CC}$ на близькосхідному напрямку в період президентства Д. Трампа ще не ставав предметом окремого дослідження в українській історіографії.

Джерельною базою цього дослідження стали документи Білого дому $[9 ; 12 ; 13 ; 16]$, Європейської служби зовнішніх справ $[2 ; 15 ; 18]$, заяви американських та європейських державних діячів $[3 ; 4 ; 11]$.

Виклад основного матеріалу дослідження. При аналізі трансатлантичних відносин в близькосхідному контексті необхідно враховувати декілька важливих обставини. По-перше, США та $€$ С н $\epsilon$ рівнозначними акторами в ступені їхнього впливу на регіональні процеси. Вашингтон володіє тут набагато більшою політичною вагою, а також військовою присутністю. В процесі врегулювання арабсько-ізраїльського конфлікту, в антитерористичній операції в Афганістані 2001 2014 pр. та в операції проти «Ісламської держави» (ІД) 2014 р., партнери з СС відігравали важливу, але допоміжну роль. Тільки в декількох випадках, наприклад, під час лівійської кризи 2011 р., ініціатива йшла від окремих європейських країн. При цьому Європа, з огляду на ії географічну наближеність до Близького Сходу, набагато більше ніж США вразлива перед загрозами, що виходять з регіону: нелегальною міграцією, ісламістським екстремізмом, поширенням зброї масового ураження.

Другорядність ролі Європейського Союзу в близькосхідних процесах зумовлена цілим набором факторів, але головний з них - це протиріччя всередині самого СС. У країн - членів $\epsilon$ свої інтереси в регіоні, що найчастіше перешкоджає виробленню єдиного європейського підходу. Це також стосується ступеню їхньої підтримки близькосхідної політики Вашингтона: одні країни демонструють схильність до підтримки американських ініціатив (до Брекзіту Великобританія, сьогодні - країни Центрально-Східної Свропи), а інші - до більш самостійної політики (Франція) [10].

Варто зазначити, що сучасні ускладнення у відносинах трансатлантичних партнерів виходять далеко за межі Близького Сходу і мають системний характер. У цій статті вони будуть розглянуті на прикладі трьох основних проблем близькосхідної безпеки: іранської ядерної програми, арабськоізраїльського конфлікту, а також сирійської кризи.

Іранська ядерна програма $\epsilon$ найбільш показовим i, водночас, принципово важливим прикладом розбіжностей в позиціях ЄС та США, з огляду на ту роль, яку грає Тегеран в сучасній системі регіональних відносин. За часів Б. Обами трансатлантичні партнери тісно співпрацювали на цьому напрямку, результатом чого стало підписання у 2015 р. ядерної угоди з Іраном - Спільного всеосяжного плану дій (СВПД). Втім, 8 травня 2018 р. Д. Трамп в односторонньому порядку вийшов із угоди та поновив санкції щодо Ірану, тим самим розгорнувши політику попередньої адміністрації на 180 градусів [16]. Ще під час своєї передвиборчої кампанії Д. Трамп неодноразово критикував 
СВПД, який, на його думку, не стримує ані іранську ядерну програму, ані підтримку Тегераном радикальних організацій в регіоні [22, с. 32].

Втім, Д. Трамп не просто вийшов із ядерної угоди: вся його близькосхідна стратегія побудована навколо стримування Ірану, який визнається загрозою номер один для американських інтересів в регіоні. 3 цією ж метою його адміністрація доклала значних зусиль до налагодження відносин між Саудівською Аравією та Ізраїлем - основними опонентами Тегерана [6, с.11].

Іран - яскравий приклад того, що сьогодні трансатлантичні партнери по-різному бачать джерела загроз в регіоні Близького Сходу, а також механізми їхньої ліквідації. Свропейський Союз, як і США, визнає сучасну деструктивну роль Тегерану в регіоні, проте він віддає перевагу дипломатії та деескалації, бажаючи не допустити військової конфронтації [15]. Крім того, європейці чітко розрізняють радикальні та помірковані сили в Ірані, сподіваючись на поступове зміцнення позицій останніх. Країни ЄС вважають СВПД важливим механізмом, який дозволяє зберігати діалог з Іраном. Односторонній вихід США з угоди, на їхню думку, є помилковим кроком, адже штовхає іранський режим на відповідні односторонні дії та інтенсифікацію своєї ядерної програми [1].

Прийнявши рішення зберегти СВПД, Свропейський Союз опинився в дуже складній ситуації. 3 одного боку, адміністрація Д. Трампа звинуватила його в підриві американських зусиль із стримування Тегерану. 3 іншого боку, європейські країни піддалися критиці з боку іранського режиму, адже, незважаючи на створення необхідних фінансових інструментів, вони не змогли компенсувати йому всі втрати від зниження торгівлі. В результаті, Іран оголосив про скорочення своїх зобов'язань із СВПД, звинувативши ЄС в недотриманні умов угоди [21].

Коли у січні 2020 р. Іран порушив останнє ключове зобов'язання, країни «євротрійки»Франція, Великобританія та Німеччина - запустили Механізм врегулювання суперечок в рамках реалізації СВПД, який, теоретично, може повернути санкції щодо Тегерану. Водночас, вони заявили, що не приєднуються до кампанії по здійсненню максимального тиску проти Ірану [5]. Більшість європейських аналітиків переконані, що Механізм буде використаний європейцями, щоб зберегти СВПД, або для досягнення нової угоди на його основі [20].

Показовим також стало те, що представники ЄС достатньо стримано відреагували на ліквідацію Сполученими Штатами іранського генерала К.С. Сулеймані, закликавши до деескалації американсько-іранського протистояння. Держсекретар США М. Помпео, в свою чергу, висловив розчарування з приводу недостатньої підтримки європейськими партнерами спецоперації США [11].

Що стосується арабсько-ізраїльського конфлікту, то тут Д. Трамп повів політику беззастережної підтримки Ізраїлю. Слід зазначити, що проізраїльські симпатії були характері і для деяких попередніх американських адміністрацій. Найчастіше, політика США у врегулюванні арабсько-ізраїльського конфлікту залежала від особистих вподобань того чи іншого президента або його радників. Однак існували певні червоні лінії, за які вони не переходили. Д. Трамп перейшов їх майже всі. Він визнав Єрусалим столицею Ізраїлю та у травні 2018 р. переніс туди американське посольство [12]. Адміністрація Д. Трампа практично повністю припинила політичний діалог із палестинцями, а також призупинила фінансування Близькосхідного агентства ООН для допомоги палестинським біженцям (БАПОР). Наступним кроком стало підписання президентської прокламації щодо визнання суверенітету Ізраїлю над Голанськими висотами [13]. Нарешті, улистопаді 2019 р. М. Помпео заявив про те, що США не вважають ізраїльські поселення на Західному березі р. Йордан такими, що суперечать міжнародному праву [4].

Жоден із вищезгаданих політичних кроків не був підтриманий Європейським Союзом як інститутом. Узгоджена позиція $Є \mathrm{C}$, оприлюднена верховним представником Ф. Могеріні, полягає у невизнанні суверенітету Ізраїлю над Голанами [2]. Європейський Союз також продовжує вважати будівництво поселень на окупованих територіях незаконним та таким, що перешкоджає врегулюванню палестинсько-ізраїльського конфлікту [18].

Що стосується Срусалиму, тут європейцям не вдалося виробити єдиний підхід. Так, Франція засудила перенесення американського посольства як таке, що суперечить міжнародному праву. Чехія, Угорщина та Румунія, навпаки, підтримали рішення Д. Трампа та відрядили своїх офіційних представників на церемонію відкриття. Румунія також оголосила про намір перенести своє посольство до Срусалиму [17].

В цілому, СС продемонстрував нездатність протипоставити що-небудь політиці Д. Трампа. У справі близькосхідного мирного врегулювання Європейський Союз не може виступати як самостійний впливовий посередник, адже не володіє для цього необхідними важелями впливу. Крім того, у своїй політиці він має враховувати той факт, що Ізраїль $є$ його важливим економічним 
партнером. На даний час $\mathrm{CC}$ забороняє організаціям на окупованих територіях доступ до фінансування. Європейська Комісія також розробила вказівки щодо маркування товарів, які там виробляють. Втім, більшість держав-членів не реалізують їх повністю [8]. За фактом єдине, що вдалося зробити Європейському Союзу, це підвищити фінансову допомогу палестинцям та БАПОР.

Довгоочікуваний американський план врегулювання близькосхідного конфлікту, оприлюднений адміністрацією Д. Трампа 28 січня 2020 р., не був узгоджений ані з СС, ані $з$ іншими членами Квартету посередників (США, СС, Росія та Китай). Основні положення плану суперечать базовим підходам ЄС до врегулювання палестинсько-ізраїльського конфлікту [9], тому, скоріше за все, призведуть до поглиблення трансатлантичних протиріч.

Що стосується сирійської кризи, то до грудня 2018 р. політика США та ЄС на цьому напрямку була досить скоординованою. ЄС в основному обмежувався гуманітарною роллю. Втім, деякі європейські країни, зокрема Франція та Великобританія, брали військову участь разом із США в операції проти «Ісламської держави» в 2014 р., а також в авіаударах по сирійських хімічних об'єктах в 2018 р. [7].

Д. Трамп неодноразово говорив про те, що американські війська залишаться в Сирії і після поразки ІД для стримування Ірану. Тому його заява про виведення контингенту з Сирії від 19 грудня 2018 р. стала повною несподіванкою для ЄС. Реакція європейських партнерів у цьому випадку була досить різкою. Зокрема, президент Франції Е. Макрон заявив, що він «глибоко шкодує про подібний крок», і що «союзник має бути надійним» [3]. У ЄС побоюються, що виведення американського контингенту дозволить Ірану зміцнити свою присутність в Сирії та в регіоні в цілому, може привести до посилення турецько-курдської конфронтації та відродження «Ісламської держави» або подібних радикальних угруповань [14].

Втім, сам СC, незважаючи на низку оприлюднених ініціатив, не зміг ефективно сприяти врегулюванню сирійської кризи, незважаючи на те, що більшість іiі драматичних гуманітарних, економічних та безпекових наслідків припадає саме на європейські країни. Головною причиною цього стала відсутність консенсусу всередині самого ЄС. 3 одного боку, сирійський криза продемонструвала розбіжності між трьома найвпливовішими державами Європи- Францією, Німеччиною та Великобританією, з іншого боку - їх небажання залучати інститути ЄС до врегулювання конфлікту, за винятком суто технічних аспектів (гуманітарна допомога та санкції) [10].

Сьогодні серед європейських країн наростає дискусія 3 приводу подальшої політики щодо сирійського режиму. У той час як Франція, Німеччина та Великобританія мають намір дотримуватися політики тиску на Асада, такі країни як Італія, Угорщина та Польща виступають за нормалізацію відносин. Вони вважають це необхідним кроком для стабілізації ситуації в Сирії та запобігання посиленню проблеми біженців [23, с. 114]

Висновки та перспективи. Таким чином, за часів перебування Д. Трампа на посаді президента США, протиріччя у підходах трансатлантичних партерів до проблем близькосхідної безпеки значно поглибилися. Основною причиною, що призвела до цього, став політичний стиль американського президента, а саме, дві його характерні складові. Перша - це непослідовність політики, при цьому мається на увазі не тільки різкий відхід від близькосхідної стратегії його попередника, але й певна хаотичність політичних кроків самого Д. Трампа. Друга - це односторонній характер прийняття рішень, коли останні приймаються без узгодження з європейськими партнерами або без врахування їхніх інтересів.

Подальші перспективи розвитку трансатлантичних відносин будуть залежати, перш за все, від американської зовнішньополітичної лінії. 3 великою ймовірністю можна прогнозувати, що в результаті переобрання Д. Трампа у 2020 р., протиріччя між США та СС збережуться чи навіть посиляться. У разі перемоги кандидата від демократів можливі зміни в підходах Сполучених Штатів щодо СВПД або до врегулювання арабсько-ізраїльського конфлікту. Втім, незалежно від того, хто прийде до влади в Вашингтоні в результаті наступних президентських виборів, можна прогнозувати подальше скорочення участі Сполучених Штатів у близькосхідних справах, яке було помітним вже під час другого президентського терміну Б. Обами.

Навпаки, для Європи важливість близькосхідного регіону зростає. Непередбачуваність американської політики, яку продемонстрував Д. Трамп, стала важливим прецедентом, який ЄС має враховувати у майбутньому. Свропейському Союзу доведеться грати більш самостійну роль у вирішенні проблем регіональної безпеки, які загрожують європейській стабільності. Однак враховуючи низку об'єктивних причин, ЄС в найближчому майбутньому не перетвориться на актора, здатного ефективно впливати на динаміку близькосхідних процесів. Тому європейцям доведеться 
більше консультуватися і співпрацювати з Росією та Китаєм, позиції яких на Близькому Сході значно посилилися продовж останніх років. Така тенденція чітко проявилася в жовтні 2018 року, коли Франція та Німеччина взяли участь у Стамбульському саміті з сирійського врегулювання разом із Росією та Туреччиною (представниками «Астанінської трійки»), за відсутністю США.

3 цього випливає інший важливий висновок: в міру самоусунення Вашингтона від близькосхідної проблематики, а також в міру зростання суперечностей як між трансатлантичними союзниками, так і між європейськими державами всередині $€ C$, в регіоні відбувається посилення альтернативних зовнішніх акторів- Росії та Китаю. Воно почалося до Д. Трампа, але стало абсолютно очевидним в роки його президентства. Сьогодні сформувалася ситуація, коли ані США, ані ЄС не мають суттєвого впливу на сирійській конфлікт - основний регіональний конфлікт сучасності. Його остаточне врегулювання, скоріше за все, відбуватиметься без урахування американських та європейських інтересів, що є ознакою важливої трансформації балансу сил на зовнішньому рівні близькосхідної регіональної системи.

\section{Бібліографічний список / References:}

1. Alcaro R., Dessi A. Last Line of Defence: A Strategy for Europe to Preserve the Iran Nuclear Deal. Istituto Affari Internazionali Research Paper. 2019. № 19. URL: https://www.iai.it/sites/default/files/iaip1914.pdf (дата звернення: 03.02.2020).

2. Declaration by the High Representative on Behalf of the EU on the Golan Heights. 27.03.2019. URL: https://eeas.europa.eu/delegations/peru/60277/declaration-high-representative-behalf-eu-golan-heights_en (дата звернення: 10.02.2020).

3. France's Macron «Deeply Regrets» Trump Decision to Withdraw US Troops from Syria. 23.12.2018. URL: https://www.france24.com/en/20181223-france-chad-macron-withdraw-troops-syria-trump-terrorism-debymilitary-sahel (дата звернення: 10.02.2020).

4. Full Text of Pompeo's Statement on Settlements. 27.11.2019. URL: https://www.timesofisrael.com/full-textof-pompeos-statement-on-settlements/ (дата звернення: 05.02.2020).

5. Geranmayer E. Europe's New Gamble: Dispute Resolution and the Iran Nuclear Deal. The European Council on Foreign Relations Commentary. 15.01.2020. URL:

https://www.ecfr.eu/article/commentary_europes_new_gamble_dispute_resolution_and_the_iran_nuclear_deal (дата звернення: 29.01.2020).

6. Indyk M. Disaster in the Desert. Why Trump's Middle East Plan Can't Work. Foreign Affairs. 2019. Vol. 98. № 6. P. 10-21.

7. Kausch K. Balancing Trumpism: Transatlantic Divergence in the Middle East. The German Marshall Fund of the United States Policy Paper. 2018. № 38. URL: http://www.gmfus.org/publications/balancing-trumpismtransatlantic-divergence-middle-east (дата звернення: 10.02.2020).

8. Oppenheim B., Scazzieri L. The EU, the US and the Middle East Peace Process: Two-state Solution or Dissolution? Center for European Reform Insight. 11.07.2019. URL: https://www.cer.eu/sites/default/ files/insight_BO_LS_11.7.19.pdf (дата звернення: 03.02.2020).

9. «Peace to Prosperity. A Vision to Improve the Lives of the Palestinian and Israeli People». 28.01.2020. URL: https://www.whitehouse.gov/wp-content/uploads/2020/01/Peace-to-Prosperity-0120.pdf (дата звернення: 02.02.2020).

10. Pierini M. The Crisis of the European Project and Its Consequences for the Euro-Mediterranean Agenda. EMed Mediterranean Yearbook 2018. URL: https://www.iemed.org/observatori/arees-danalisi/arxius-adjunts/ anuari/med.2018/IEMed_Crisis_EU_project_Medyearbook2018_Marc_Pierini.pdf (дата звернення: 10.02.2020).

11. Pompeo: European Response to Suleimani Killing «not Helpful Enough». 04.01.2020.

URL: https://www.theguardian.com/us-news/2020/jan/04/mike-pompeo-european-response-to-suleimani-killing (дата звернення: 10.02.2020).

12. Presidential Proclamation Recognizing Jerusalem as the Capital of the State of Israel and Relocating the United States Embassy to Israel to Jerusalem. 06.12.2017. URL: https://www.whitehouse.gov/presidential-actions/ presidential-proclamation-recognizing-jerusalem-capital-state-israel-relocating-united-states-embassy-israel-jerusalem/ (дата звернення: 25.01.2020).

13. Proclamation on Recognizing the Golan Heights as Part of the State of Israel. 25.03.2019. URL: https://www.whitehouse.gov/presidential-actions/proclamation-recognizing-golan-heights-part-state-israel/ (дата звернення: 25.01.2020).

14. Rapnouil M. Alone in the Desert? How France Can Lead Europe in the Middle East. The European Council on Foreign Relations Policy Brief. April 2018. URL: https://www.ecfr.eu/page/-I alone_in_the_desert_how_france_can_lead_europe_in_the_middle_east_pdf (дата звернення: 10.02.2020).

15. Remarks by HR/VP Mogherini at the Press Conference Following Ministerial Meetings of the EU/E3 and Iran. 15.05.2018. URL: https://eeas.europa.eu/headquarters/headquarters-homepage/44599/ remarks-hrvp-mogherini-press-conference-following-ministerial-meetings-eue3-and-eue3-and-iran_en (дата звернення: 10.02.2020). 
16. Remarks by President Trump on the Joint Comprehensive Plan of Action. 08.05.2018.

URL: https://www.whitehouse.gov/briefings-statements/remarks-president-trump-joint-comprehensive-plan-action/ (дата звернення: 25.01.2020).

17. Scazzieri L. A Troubled Partnership: The US and Europe in the Middle East. Center for European Reform Policy Brief. July 2019. URL: https://www.cer.eu/sites/default/files/pbrief_middle_east_10.7.19.pdf (дата звернення: 02.02.2020).

18. Statement by High Representative/Vice-President Federica Mogherini on Israeli Settlement Policy. 18.11.2019. URL: https://eeas.europa.eu/delegations/palestine-occupied-palestinian-territory-west-bank-and-gazastrip/70610/statement-high-representativevice-president-federica-mogherini-israeli-settlement-policy_en (дата звернення: 10.02.2020).

19. Stelzenmuller C. Hostile Ally. The Trump Challenge and Europe's Inadequate Response. Brookings Institutions Report. August 2019. URL: https://www.brookings.edu/wp-content/uploads/2019/08/ FP_20190905_hostile_ally.pdf (дата звернення: 05.02.2020).

20. Thepaut C., DeLozier E. Europe Is Creating an Opportunity for Iran Talks, and Washington Should Take It. The Washington Institute for Near East Policy PolicyWatch. 2020. № 3242. URL: https://www.washingtoninstitute.org/policy-analysis/view/europe-is-creating-an-opportunityfor-iran-talks-and-washington-should-take (дата звернення: 10.02.2020).

21. Therme C. The Rise of Tensions between Iran and Europe: the Trump Factor. The International Institute for Security Studies Analysis. 01.03.2019. URL: https://www.iiss.org/blogs/analysis/2019/03/iran-and-europe-riseof-tensions (дата звернення: 29.01.2020).

22. Wechsler W. US Withdrawal from the Middle East: Perceptions and Reality / Mezran K., Varvelli A. eds, The MENA Region: a Great Power Competition. Atlantic Council. 2019. P. 13-39. URL: https://atlanticcouncil.org/ wp-content/uploads/2019/10/MENA-Region-Great-Power-Competition-Report-Web-2.pdf (дата звернення: 10.02.2020).

23. Zakharchenko A. The EU Policy towards Syria after 2011 / Brusilovska O., Koval I. eds, Prospects of Development in EU Politics: Global and Regional Dimensions. Odessa: Odessa Mechnikov National University Press, 2019. P. 103-116.

\section{Zakharchenko A. M. The US-EU relationship in the context of security challenges in the Middle East under the D. Trump presidency}

The purpose of this article is to analyze the transatlantic relations in the Middle East under the D. Trump administration. The research presents comparative analysis of US and EU policy toward main regional security issues - the Iranian nuclear program, the Arab-Israeli conflict and the Syrian crisis. It also examines the differences in American and European approaches to these problems and their impact on the transatlantic relations.

The author came into conclusion that under the D. Trump presidency the contradictions between two actors in the Middle East have deepened. This was due to D. Trump's abrupt departure from the policies of his predecessors, as well as to his unilateral decision making. A series of contradictory steps by the American president were not supported by European allies: withdrawal from the agreement on the Iranian nuclear program; US unconditional support to Israel, including the relocation of the US embassy to Jerusalem and recognition of Israeli sovereignty over the Golan Heights; the decision to withdraw troops from Syria.

While the United States is showing a declining interest in the Middle East, the importance of the region for European security is growing. Trump administration's unilateral steps, as well as the differences in US and European views on important regional security issues, will require a more independent policy on the part of the European Union. However, a number of objective circumstances, above all, contradictions within the EU itself, do not allow it to act as an effective actor in the Middle East. If US involvement in the region wanes, Europe will increasingly be pushed to work with alternative powers, such as Russia and China, to further its interests.

Key words: the USA, the EU, the Middle East, problems of security, D. Trump. 